慶應義塾大学学術情報リポジトリ

Keio Associated Repository of Academic resouces

\begin{tabular}{|c|l|}
\hline Title & Monoamine oxidase activity in rat brain and estrous cycle \\
\hline Sub Title & \\
\hline Author & $\begin{array}{l}\text { 木村, 都(Kimura, Miyako) } \\
\text { 小林, 礼子( Kobayashi, Reiko) } \\
\text { 中村, 悦郎( Nakamura, Etsuro) }\end{array}$ \\
\hline Publisher & 共立薬科大学 \\
\hline Publication year & 1978 \\
\hline Jtitle & $\begin{array}{l}\text { 共立薬科大学研究年報 (The annual report of the Kyoritsu College of } \\
\text { Pharmacy). No.23 (1978. ),p.134- 134 }\end{array}$ \\
\hline JaLC DOI & \\
\hline Abstract & \\
\hline Notes & 学会講演要旨 \\
\hline Genre & Technical Report \\
\hline URL & https://koara.lib.keio.ac.jp/xoonips/modules/xoonips/detail.php?koara_id=AN00062898-0000002 \\
& 3-0138 \\
\hline
\end{tabular}

慶應義塾大学学術情報リポジトリ(KOARA)に掲載されているコンテンツの著作権は、それぞれの著作者、学会または出版社/発行者に帰属し、その権利は著作権法によって 保護されています。引用にあたっては、著作権法を遵守してご利用ください。

The copyrights of content available on the KeiO Associated Repository of Academic resources (KOARA) belong to the respective authors, academic societies, or publishers/issuers, and these rights are protected by the Japanese Copyright Act. When quoting the content, please follow the Japanese copyright act. 
No.23 (1978)

的低く，E I 期にピークが現われた。卵巣摘出（14日後）によって MAO 活性は有意の上昇を， cyclic nucleotidesはやや減少傾向を示した。即巣摘出ラット（対照群とする）に steroids を投 与したとき, MAO 活性は estradiol で低下し, progesterone で対照群レベルに回復し, cGMP はMAO 活性と類似した態度を示したが, cAMP は逆に estradiol で有意に増加, progesterone で著明に減少した。MAO 活性の性周期による変動パターン，あるいは投与された steroidsによ る影響は CGMP のそれと類似するが， cAMP との間には関連が認められない。P期は estrogen の血中濃度の最も高い時期といわれ，いわゆる critical periodに相当する。子宮内膜中の MAO 活性あるいは cyclic nucleotides の性周期による変動は内因性の estrogen レベルとは直接の関 連性を持たないと考えられる。

\title{
Monoamine Oxidase Activity in Rat Brain and Estrous Cycle
}

\author{
MiYako KImURA, ReIKo Kobayashi and ETsUro NAKAMURA \\ 木村 都，小林礼子，中村悦郎
}

〔7th International Congress of Pharmacology, Paris, France, (July 16-21, 1978) で発表〕

The activity of monoamine oxidase (MAO) during different phases of the estrous cycle was studied using seven brain regions obtained from S. D. strain rats by the method of Glowinski and Iversen. The enzyme activity of homogenate of each tissue was assayed by our modified Otsuka's method using ${ }^{14} \mathrm{C}$-tyramine as substrate. In most regions of the brain, MAO activity was highest in proestrus, subsequently fell in estrus I, rose again slightly in estrus II in the regions except hypothalamus, and turned to a lower level during diestrus. Hypothalamus and medulla oblongata showed highest activity in proestrus among the rest. This pattern of fluctuation of MAO activity in the brain differed from that in endometrium in the point that the level of the activity in the later was lowest in estrus II. $17 \beta$-Estradiol $(0.2 \mathrm{mg} / \mathrm{kg} / \mathrm{day}$ for 3 days $)$ depressed the activity, whereas progesterone $(4 \mathrm{mg} / \mathrm{kg} /$ day for 3 days) had a tendency to elevate the activity, when these were injected subcutaneously to intact or ovariectomized rats. The pattern of the activity in hypothalamus resembles that of plasma levels of estrogens during sexual cycle. The peak of the activity seems to come almost simultaneously with the so called critical period. And then, the fluctuation of MAO activity in hypothalamus can not be attributed to the levels of endogenous steroids. 